\title{
Prevalence and risk factors for intestinal parasitic infections in pregnant women residing in three districts of Bogotá, Colombia
}

Angela Fernanda Espinosa Aranzales ${ }^{1,2^{*}} \mathbb{D}$, Katja Radon ${ }^{2,3}$, Guenter Froeschl ${ }^{2,4}$, Ángela María Pinzón Rondón ${ }^{1}$ and Maria Delius ${ }^{2,5}$

\begin{abstract}
Background: Intestinal parasitic infections (IPI) lead to significant morbidity and mortality in pediatric and adult populations worldwide. Intestinal parasitism during pregnancy is of interest as it may affect the health of pregnant women and their offspring. This study determined the prevalence of IPI in pregnant women living in substandard conditions in three urban districts of Bogotá, Colombia. Associations between prevalence and sociodemographic factors, housing, and living conditions were also evaluated.

Methods: In a cross-sectional and community-based study, pregnant women were recruited from three districts of Bogotá. A total of 550 participants answered a questionnaire; 331 of these also provided stool samples, with 233 providing one and 98 providing two stool samples. Questionnaire responses were associated with the presence of intestinal parasites, which was determined using a standard combined microscopy technique including direct wet mount and formol-ether concentration. Results were verified by supplementary examination of 48 stool samples by quantitative polymerase chain reaction (qPCR).
\end{abstract}

Results: Among pregnant women who lived in selected poor residential areas in Bogotá, the overall prevalence of intestinal parasitism was 41\% with 9\% polyparasitism. Pathogenic parasites were present in 1.2\% of the 331 participants including Giardia lamblia and Ascaris lumbricoides. Higher prevalence was found for parasites with debated pathogenicity, including Blastocystis hominis (25\%), Endolimax nana (15\%), Entamoeba coli (8\%), and lodamoeba butschlii (2\%). Entamoeba histolytica/dispar complex was also detected (1.5\%). When comparing a subset of stool samples using the combined microscopy technique and qPCR, the latter detected a higher 58.3\% overall IPI prevalence. Higher prevalence of infections by any intestinal parasite was found in participants who had never been dewormed $(p=0.01)$. Higher but not statistically significant associations were found between any parasite and women living with a partner, and intestinal polyparasitism and being from a minority group and not having a water sink.

Conclusions: This first study of the prevalence of intestinal parasitism in Bogotá focused on pregnant women living in poverty, found a high prevalence of intestinal parasites of debated pathogenicity, and confirmed a low prevalence of pathogenic intestinal parasites. These results highlight the need for educational interventions to disrupt transmission routes for prevalent parasites.

Keywords: Intestinal parasitic infections, Pregnant women, Vulnerable populations, Sociodemographic factors, Housing, Living conditions

\footnotetext{
* Correspondence: angela.espinosa@urosario.edu.co

'Escuela de Medicina y Ciencias de la Salud, Universidad del Rosario, Bogotá, Colombia

${ }^{2}$ Center for International Health, Medical Center of the University of Munich

(LMU), Munich, Germany

Full list of author information is available at the end of the article
}

(c) The Author(s). 2018 Open Access This article is distributed under the terms of the Creative Commons Attribution 4.0 International License (http://creativecommons.org/licenses/by/4.0/), which permits unrestricted use, distribution, and reproduction in any medium, provided you give appropriate credit to the original author(s) and the source, provide a link to the Creative Commons license, and indicate if changes were made. The Creative Commons Public Domain Dedication waiver (http://creativecommons.org/publicdomain/zero/1.0/) applies to the data made available in this article, unless otherwise stated. 


\section{Background}

The World Health Organization (WHO) estimates that at least one quarter of the world's population is infected with soil-transmitted helminths [1]. Consequences of infections are compromised growth, cognitive impairment, malnutrition, and anemia [2-4]. Worldwide, about 300 million people suffer from severe helminth infections, leading to morbidity and over 150,000 deaths annually [5]. Amoebiasis caused by Entamoeba histolytica kills between 40,000 and 100,000 people per year [6], whereas giardiasis is the main cause of parasitic diarrhea worldwide [7] and an important cause of waterborne disease outbreaks $[8,9]$. Housing conditions are an important determinant for developing intestinal parasitic infections (IPI) $[4,10,11]$. Risk factors for these infections include deprivation of access to clean water, inadequate hygiene habits, and inferior sanitary conditions [12-14]. As in the case of other neglected diseases, poverty in general is a condition correlating with IPI [15]. Although factors associated with parasitism in pregnant women are mainly the same as in other population groups [16], multiparity is an additional risk factor [17]. On a larger scale, people living below the poverty line in low-income countries, especially young women and young pregnant women, their infants, and children, are at a high risk of IPI [2]. Among these high-risk groups, IPI studies have focused primarily on children, while data on women of childbearing age are scarce. Therefore, considering that IPI have significant consequences for pregnant women and their offspring, including maternal anemia [4, 18], low pregnancy weight gain, poor fetal growth [19], low birth weight [20], and preterm birth [4], pregnant women are an important population for study. Among intestinal parasites, the WHO considers soil-transmitted helminthiasis (STH) as the most common infections in vulnerable populations [5]. Prevalence studies in Latin American populations report wide ranges from $1 \%$ up to 97\% [2]. In Colombia, STH prevalence data range between 11 and 50\% [2, 21]. More specifically, for Bogotá, the capital city, prevalence has been reported to be from 1.5 to $10 \%$ [22].

The most common enteric protozoa in humans are Giardia lamblia, Entamoeba histolytica, and Blastocystis hominis $[23,24]$. Although giardiasis has a ubiquitous distribution, it is more prevalent in developing countries [25]. Its worldwide prevalence of about 3\% [26] contrasts with 8-67\% reported for Latin America as a whole [24, 27, 28], 13-17\% for Colombia [21, 29], and 12-20\% for Bogotá [22, 30, 31]. Entamoeba histolytica infection, estimated to affect $12 \%$ of the population worldwide [32], is more prevalent in tropical regions. In Latin America, prevalence has been reported between 4 and 12\% [19,33, 34], in Colombia between 0 and $54 \%[21,29,35,36]$, and in Bogotá between 0 and $3 \%[22,30]$. With its pathogenicity still debated [12], worldwide prevalence of Blastocystis hominis has been reported to be as high as $100 \%$ [37, 38], while in Latin America it is reported to be between 22 and $67 \%$, in Colombia between 6 and 54\% [21, 29, 39], and at 3\% in Bogotá [30].

Bogotá lies in the center of Colombia at $2600 \mathrm{~m}$ above sea level $\left(4^{\circ} 35^{\prime} 56 \mathrm{~N}, 74^{\circ} 04^{\prime} 51 \mathrm{~W}\right)$ and is located within an intertropical zone with an annual average temperature of $14{ }^{\circ} \mathrm{C}$ and about $80 \%$ humidity [40]. Despite being the largest and most developed city in Colombia, Bogotá exhibits great inequality between rich and poor, reflected in a 2016 GINI index of 0.499 [41]. Of its 8 million inhabitants [42], 9.2\% of the population of Bogotá cannot afford one or more of their basic needs, as defined by the Colombian National Administrative Department of Statistics [43], 11.6\% live in poverty, and $2.3 \%$ live in extreme poverty. It is estimated that more than 400,000 displaced people live in Bogotá [44], most of them living in conditions of inadequate sanitation and overcrowding [45]. Bogotá has an urban area of $384 \mathrm{~km}^{2}$ [46] divided into 20 districts, which are administrative units with different features and resources and, just as in the rest of the country, are categorized into socioeconomic strata based on housing and neighborhood conditions. Strata range from 1, indicating substandard housing conditions, to 6 with high-level housing conditions [47]. Stratification is based on a reference index of living standards, inequality, and poverty. Geographically, strata identify regions in which people share similar social and economic characteristics [48]. A given urban district may contain several different strata.

Following the Colombian Ministry of Health and Social Protection, adhering to the 2002 WHO recommendations, Colombia has implemented preventive antiparasitic treatments in at-risk populations [49]. According to these guidelines, control programs target mostly healthy school-aged children who live in endemic areas by providing prophylactic and periodical broad-range antihelminthic treatments, with suboptimal coverage below the $75 \%$ target. In large non-endemic urban areas such as Bogotá, children should receive one yearly prophylactic dose, but pregnant women should not receive these prophylactic treatments. In parallel, community-based control programs focus on education, hygiene habits, food handling, and adequate public and residential sanitation services to disrupt parasitic life cycles.

This study investigated the magnitude of IPI in pregnant women in poor residential areas in Bogotá and identified risk factors associated with these infections. The results and recommendations of this study will provide evidence for stakeholders in health care and public health, geared toward implementing and improving preventive measures in pregnant women, especially in poor residential areas. 


\section{Methods}

\section{Study design}

A cross-sectional, community-based study, in which participants answered a questionnaire and provided one or two stool samples, was conducted between May 2015 and July 2016 in Bogotá. This study focused on pregnant women living in poor residential areas in three districts of Bogotá (Fig. 1). These communities were selected because they have a majority of strata 1 and 2 neighborhoods or receive a large number of people displaced within Colombia [50], who live in socioeconomic and geographical conditions that may affect their risk of IPI. The selected districts were Usaquén (population 472,908; area $65.31 \mathrm{~km}^{2}$ ), Kennedy (population 1,187,315; area $38.56 \mathrm{~km}^{2}$ ), and Ciudad Bolívar (population 719,700; area $\left.129.98 \mathrm{~km}^{2}\right)[42,51]$.

\section{Study population and sample}

Colombia's health care system is organized into three levels of attention with primary care units (Unidad Primaria de Atención or UPA) within a basic level of health care and secondary and tertiary care hospitals. In Bogotá, antenatal care in public health settings is provided in UPAs with high-risk cases being referred. The study's target population was all pregnant women in any trimester, living in the districts of Usaquén, Kennedy, and Ciudad Bolívar, belonging to strata 1 or 2 , and attending antenatal care in local primary care units. During the study period, a total of about 9600 pregnant women attended these units.

To calculate the sample size in this study, the Epi Info $^{\text {тм }} 7.2$ software developed by the Center for Disease Control and Prevention (CDC, Atlanta, GA, USA) was used. More specifically, using the StatCalc module for cross-sectional studies, sample size was estimated based on exposure and outcome prevalence reported in previous similar studies in Colombian and Venezuelan cohorts. These reported 43\%, 12\%, and 9.5\% parasitism in groups exposed to unfavorable socioeconomic and sanitary conditions, in contrast to $33 \%$ and estimated $6 \%$ and $4.5 \%$ in unexposed groups [22, 24], with estimated ORs of $1.53,2.14$, and 2.23 respectively. The different sample sizes were determined with a level of accuracy of $5 \%$ and statistical power of $80 \%$. Thus, sample sizes of 776, 778, and 894 were calculated. Considering a non-response proportion of $20 \%$, the resulting estimated sample size was 1100 pregnant women.

\section{Data collection}

With respect to national data protection regulations, it was not possible to access patient databases directly to establish a sample frame of pregnant women who attended the primary care units within the three districts. Therefore, from May 2015 to July 2016, research assistants proactively invited pregnant women to participate in the study. Fieldwork was supported by six research assistants experienced in community work who had received training in technical, ethical, and logistic procedures before data collection. Once the informed consent form was signed, each woman received a kit and instructions for appropriate stool collection. Sociodemographic aspects and pregnancy characteristics were assessed at the UPAs through individual interviews, while data related to housing conditions and hygiene habits were assessed through questioning complemented with inspection during home visits. Once the questionnaire was completed, pregnant women received an educational intervention about general health recommendations and danger signs during pregnancy. Afterwards, participants received their exam results with a recommendation to include them in the next visit to the physician. Fieldwork started in the districts of Usaquén and Kennedy. In these districts, research

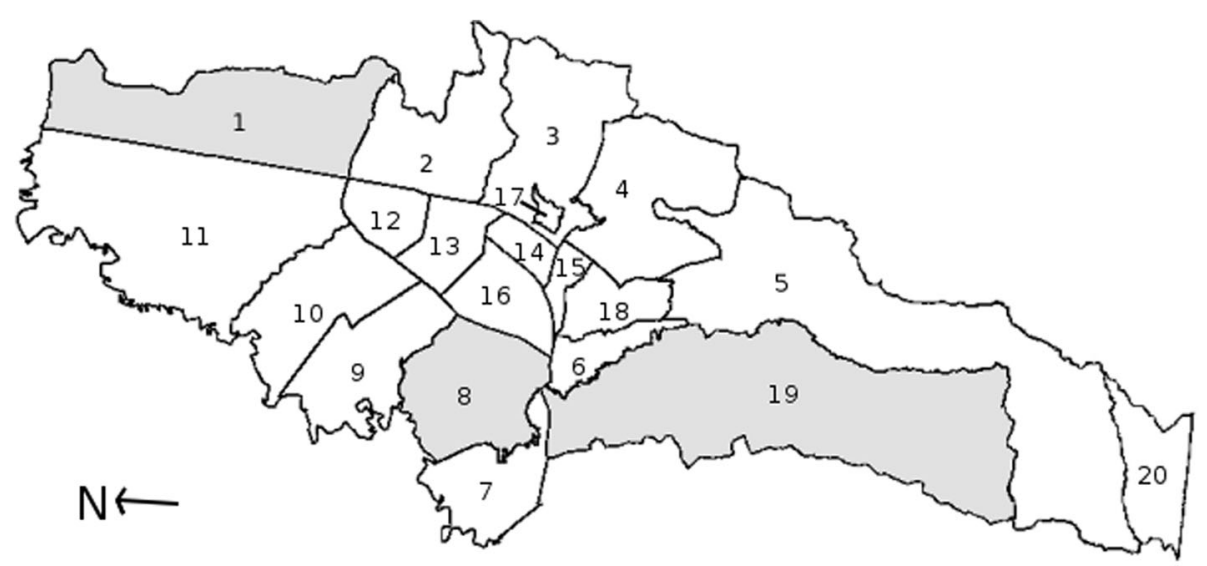

Fig. 1 Map of Bogotá districts. Three districts were selected to study the prevalence of intestinal parasitism in pregnant women living in the largest city in Colombia. 1. Usaquen District. 8. Kennedy District. 19. Ciudad Bolivar District. Adapted from: Louise Wolff, 2006 (Own work, Public Domain; commons license permission granted worldwide to use for any purpose and without any conditions) [92] 
assistants approached pregnant women directly before and after prenatal courses at UPAs and, in addition, in Usaquén, they included door-to-door visits. Ciudad Bolívar was the last district, in which research assistants systematically invited every pregnant woman who attended any time between 7 am and $4 \mathrm{pm}$ at two UPAs selected within the district because both received $80 \%$ of pregnant women from the district. In the district of Usaquén, recruitment had to be suspended as a result of unsafe working conditions for research assistants when neighborhood conditions deteriorated during the period of fieldwork. This led to an underrepresented $4 \%(24 / 550)$ sample of participants in this district. In the district of Kennedy, the recruitment of participants was stopped because of selective sampling in favor of the pregnant women who could attend courses at the UPA. Consequently, only $23 \%(127 / 550)$ of the study participants were from that district. For these reasons, 73\% of the participants were from Ciudad Bolívar, the district of Bogotá where $59 \%$ of people live in stratum 1 and $38 \%$ in stratum 2 [52].

Of the 210 participants who did not provide stool samples, 95\% (199/210) were from the district of Ciudad Bolívar, of whom $84 \%(167 / 199)$ resided in stratum 1 (Table 1). This district is located on a mountain with the poorest homes near the top, where access is difficult and not always feasible for geographical and safety reasons. Despite these limitations in accessing these participants, research assistants attempted data collection when conditions allowed. Additionally, some pregnant women who initially answered the questionnaire in the local primary care units did not accept the home visit to pick up the stool sample and did not hand in the sample to the units.

A total of 775 pregnant women were invited to participate: of these, $71 \%(550 / 775)$ accepted the invitation; of the latter, 94\% (519/550) answered the questionnaire completely and $62 \%(340 / 550)$ gave one stool sample. Of the 340 participants who provided a stool sample, 32\% $(107 / 340)$ provided a second stool sample, nine of which had to be excluded because of processing errors. Thus, this study included 331 participants with at least one stool sample, 98 of whom provided a second stool sample. In addition, of the 331 participants, a subgroup of 50 samples was processed further for quantitative polymerase chain reaction (qPCR) investigation. Two of these samples were lacking formol-ether concentration data, so they were excluded from further comparison, resulting in 48 samples included for molecular analysis.

\section{Questionnaire}

The interviewer-administered questionnaire was adopted from the Demographic and Health Surveys (DHS) to assess sociodemographic conditions as implemented by ICF International (Fairfax, VA, USA) [53]. The items included were age, occupation, education level, civil status, health insurance coverage, monthly income, household conditions, water availability, supply, and sewage, and hygiene habits such as boiling water before drinking, washing fruit and vegetables, place and reasons for washing hands throughout the day, and habits of walking barefoot. Two research members (AE and KR) translated the questionnaire from English into Spanish. In addition, questions about parity and trimester of pregnancy were taken from a Spanish form on "Pregnant women in primary health care" [54]. Items on garbage collection, vectors, and living with pets were chosen from the Spanish form on "Elementary family characteristics" [55], both developed by the Health District Secretary of Bogotá. Supplementary questions regarding the location of the house, socioeconomic stratum, and date of the last deworming procedure were included. A pilot test of the questionnaire to control for clarity, comprehension, and duration of the survey was carried out with three students from Universidad del Rosario, Bogotá. They were in their fifth year of medical school and received training by two investigators ( $\mathrm{AE}$ and $\mathrm{AP}$ ) to apply the survey. Ten women residing in the district of Usaquén who were in their last month of pregnancy were interviewed once they gave their informed consent. These women were not included as participants in the study. Minor wording adjustments were made following their feedback.

\section{Stool sample collection and laboratory methods}

All study participants received stool sample containers and standard instructions on proper and safe collection and preservation of the samples. By agreement, research assistants contacted participants by phone to insure that, once the sample was collected and stored in proper conditions (inside the fridge or in a dark low-temperature home location), the assistants could pick it up from the participants' homes no more than $4 \mathrm{~h}$ after evacuation. The research assistants, who were trained in biosafety standards, followed a protocol for stool sample collection and handling, including appropriate labeling, triple packaging [56], keeping the cooling chain, and ensuring proper, timely, and safe handling and delivery of stool samples to the laboratory.

\section{Combined microscopy technique}

The detection techniques selected in this study were based on diagnostic performance, methodological availability, feasibility, and cost-effectiveness [57]. In this study, each stool sample was analyzed by a so-called "combined microscopy technique", which included sample analysis by direct wet mount microscopy and by a formol-ether concentration method and subsequent microscopy [58]. Both methods were performed by a contracted specialized nationwide reference laboratory following standard procedures. 
Table 1 Characteristics of participants who answered the questionnaire and participants who also provided one stool sample

\begin{tabular}{|c|c|c|c|c|c|c|c|}
\hline \multirow[t]{3}{*}{ Characteristic } & \multicolumn{3}{|c|}{ Participants with questionnaires only } & \multicolumn{3}{|c|}{ Participants with questionnaires and stool samples } & \multirow[t]{3}{*}{$p$ value } \\
\hline & \multicolumn{3}{|c|}{ Total: 210} & \multicolumn{3}{|c|}{ Total: 340} & \\
\hline & $\mathrm{N}_{\text {missing }}$ & N & $\%$ & $N_{\text {missing }}$ & $\mathrm{N}$ & $\%$ & \\
\hline \multicolumn{8}{|l|}{$\overline{\text { City district of Bogotá }}$} \\
\hline Ciudad Bolívar & 0 & 199 & 94.8 & 0 & 200 & 58.8 & $<0.001$ \\
\hline Kennedy & & 9 & 4.3 & & 118 & 34.7 & \\
\hline Usaquén & & 2 & 1.0 & & 22 & 6.5 & \\
\hline \multicolumn{8}{|l|}{ Stratum ${ }^{a}$} \\
\hline One & 0 & 168 & 80.0 & 0 & 172 & 50.6 & $<0.001$ \\
\hline Two & & 42 & 20.0 & & 168 & 49.4 & \\
\hline \multicolumn{8}{|l|}{ Ethnicity } \\
\hline Minority group ${ }^{b}$ & 0 & 14 & 6.7 & 1 & 24 & 7.1 & 0.5 \\
\hline Majority group & & 196 & 93.3 & & 315 & 92.9 & \\
\hline \multicolumn{8}{|l|}{ Occupation } \\
\hline Family maker/housewife & 0 & 156 & 74.3 & 0 & 265 & 77.9 & 0.436 \\
\hline Student & & 19 & 9.0 & & 35 & 10.3 & \\
\hline Sales and services & & 19 & 9.0 & & 22 & 6.5 & \\
\hline Other & & 16 & 7.6 & & 18 & 5.3 & \\
\hline \multicolumn{8}{|l|}{ Level of education } \\
\hline Elementary school & 0 & 35 & 16.7 & 0 & 38 & 11.2 & 0.116 \\
\hline Secondary school & & 147 & 70.0 & & 243 & 71.5 & \\
\hline Higher education & & 28 & 13.3 & & 59 & 17.4 & \\
\hline \multicolumn{8}{|l|}{ Civil status } \\
\hline Single & 0 & 67 & 31.9 & 0 & 103 & 30.3 & 0.380 \\
\hline Married or cohabiting & & 143 & 68.1 & & 237 & 69.7 & \\
\hline \multicolumn{8}{|c|}{ Covered by social health insurance } \\
\hline Yes & 0 & 168 & 80.0 & 0 & 300 & 88.2 & 0.010 \\
\hline No & & 42 & 20.0 & & 40 & 11.8 & \\
\hline \multicolumn{8}{|l|}{ Victim of forced displacement } \\
\hline Yes & 0 & 41 & 19.5 & 0 & 66 & 19.4 & 0.974 \\
\hline No & & 169 & 80.5 & & 274 & 80.6 & \\
\hline \multicolumn{8}{|l|}{ Monthly income } \\
\hline$\leq 1$ Minimum wage & 48 & 108 & 66.7 & 18 & 245 & 76.1 & 0.088 \\
\hline$>1$ Minimum wage & & 54 & 33.3 & & 77 & 23.9 & \\
\hline \multicolumn{8}{|l|}{ Parity } \\
\hline Nulliparous & 2 & 100 & 48.1 & 1 & 185 & 54.6 & 0.140 \\
\hline Multiparous & & 108 & 51.9 & & 154 & 45.4 & \\
\hline \multicolumn{8}{|l|}{ Trimester } \\
\hline First & 13 & 43 & 21.8 & 6 & 63 & 18.9 & 0.202 \\
\hline Second & & 74 & 37.6 & & 152 & 45.5 & \\
\hline Third & & 80 & 40.6 & & 119 & 35.6 & \\
\hline \multicolumn{8}{|c|}{ Last deworming of participant } \\
\hline Less than 1 year ago & 31 & 28 & 15.7 & 32 & 62 & 20.1 & 0.200 \\
\hline More than 1 year ago & & 77 & 43.0 & & 109 & 35.4 & \\
\hline Never & & 74 & 41.3 & & 137 & 44.5 & \\
\hline
\end{tabular}

Socioeconomic classification in Colombia

${ }^{\mathrm{b}}$ Afrocolombian and native ethnic people

${ }^{c}$ Minimum monthly Colombian income (for 2016) = USD 233 
Direct wet mount microscopy has reportedly shown better diagnostic capacity for protozoal trophozoites, especially Giardia [57] and Blastocystis [59], while the concentration technique has demonstrated better performance for other protozoa [59] and for helminths [60, 61].

\section{qPCR}

In this study, a subgroup of 48 stool samples was subsequently analyzed by qPCR for comparison with the results obtained by standard microscopy detection techniques. These samples originated from participants residing in Ciudad Bolívar district and were selected prospectively and chronologically by order of arrival at the laboratory. For financial reasons, not all samples could be analyzed by qPCR. The qPCR technique, with $100 \%$ primer-determined specificity and reported sensitivity close to $100 \%$ [62, 63], was carried out by the microbiology laboratory of Universidad del Rosario, Bogotá.

At the university laboratory, the stool sample was fixed with $70 \%$ ethanol. With $300 \mu \mathrm{l}$ of the fixed sample, DNA was extracted using the Norgen Stool DNA isolation kit (Norgen Biotek Corporation, Thorold, Canada) following the manufacturer's protocol. The PCR was conducted on a total volume of $7 \mu \mathrm{l}$ containing $3.5 \mu \mathrm{l}$ of Taqman Mastermix $^{\text {tix }}$ (Applied Biosystems, Foster City, CA, USA), $2 \mu \mathrm{l}$ of DNA, and $1.5 \mu \mathrm{l}$ of species-specific primers (final concentration $=900 \mathrm{mM}$ ) and Taqman probes (final concentration $=100 \mathrm{mM}$ ). Samples were run in an Applied Biosystems 7500 Fast Real-Time PCR system and processed using a denaturation time of $3 \mathrm{~s}$ at $95{ }^{\circ} \mathrm{C}$ and an extension time of $30 \mathrm{~s}$ at $60{ }^{\circ} \mathrm{C}$ for 40 cycles. The results of qPCR were considered negative if the cycle threshold values $(\mathrm{Ct})$ were $>38$. This threshold was determined by measuring the detection limits of each assay in which serial dilutions of parasites were included [64]. The available PCR primers were: Blastocystis hominis, Giardia lamblia, Cryptosporidium, Entamoeba histolytica, Ancylostoma duodenalis, Necator americanus, Ascaris lumbricoides, and Trichuris trichiura, all of which were based on the primers reported by Mejia et al. [64], except the primer for B. hominis, which was based on Stensvold et al. [65]. A reference strain of Giardia duodenalis WB and DNA from each of the parasites were used as positive controls. Stool samples previously collected and confirmed by the laboratory to be from healthy non-infested children served as negative controls.

\section{Data analysis}

All data were double entered and controlled for errors. Data analysis was performed using IBM SPSS Statistics version 24 software (Armonk, NY, USA). A comparison of sociodemographic characteristics was performed between the 210 pregnant women who answered the questionnaire only and the 340 participants who also provided a stool sample.

Laboratory reports indicated the presence of any parasite form (trophozoites, cysts, eggs, or larvae) as detected by direct and concentration techniques separately and for each parasite. With these data, one variable for each parasite was defined as "negative $=0$ " (if no form was reported) or "positive = 1" (if any parasite form was reported). Once the prevalence of each parasite was established with each technique, a pooled analysis with both techniques was generated. A combined variable for each parasite was created and defined as "negative $=0$ " (if no parasite was detected by either technique) or as "positive = 1" (if any parasite was detected by either technique). In all included participants, the prevalence was analyzed in three dimensions, namely the presence of any parasite, the presence of any pathogenic parasite, and the presence of more than one parasite ("polyparasitism"). For each outcome dimension, one compound variable was created and defined as "negative $=0$ " (if no parasite forms were detected with the combined microscopy technique) or "positive $=1$ " (if parasite forms were detected with the combined microscopy technique).

When qPCR was added to the combined microscopy technique in a subgroup of participants, the prevalence of each parasite was established separately and combined by creating variables, as described above. The percentage of agreement between the two techniques was then determined. Positive agreement percentage was estimated as a proportion corresponding to the number of parasites detected by combined microscopy technique and confirmed by qPCR over the total number of parasites detected by qPCR. Negative agreement was estimated as a proportion corresponding to the number of stool samples reported as negative for parasites by combined microscopy technique and confirmed by qPCR over the total negative cases detected by qPCR [66].

Exposure variables such as sociodemographic and pregnancy characteristics, living conditions, and hygiene habits were evaluated as categorical variables and presented as absolute and relative frequencies. Age was evaluated numerically. Bivariate analysis was done using Pearson's Chi-square $\left(x^{2}\right)$ test, Fisher's exact test, or Mann-Whitney test as appropriate. Factors that correlated highly with the polyparasitism variable $(p<0.1)$ were included in a logistic regression analysis.

\section{Results}

General characteristics of the participants

Of the 550 pregnant women who agreed to participate, $38 \%(210 / 550)$ only answered the questionnaire and $62 \%$ $(340 / 550)$ responded to the questionnaire and handed in one stool sample. Sociodemographic conditions based on participant characteristics were compared between 
participants only responding to the questionnaire and those additionally providing a stool sample. Statistically significant differences were identified according to district, stratum, and health insurance coverage between participants who only answered the questionnaire and those who also provided a stool sample $(p<0.001)$. Among the women who answered the questionnaire only, 94.8\% (199/210) resided in Ciudad Bolívar, 80\% $(168 / 210)$ lived in stratum 1 , and $80 \%$ (168/210) were covered by social health insurance (Table 1). In addition, the median age for participants who only answered the questionnaire was 21 years (range 15-41 years), while the median age for those who also provided a stool sample was 22 years (range 14-43 years), $p=0.034$. All other variables showed no statistically significant differences.

\section{Prevalence of intestinal parasitic infections in pregnant women}

Nine participants from the 340 (3\%) who delivered at least one stool sample had to be excluded because of processing errors in the laboratory. Of the remaining 331 participants, 107 (32\%) voluntarily provided a second stool sample, and nine of the $107(8 \%)$ had to be excluded because of processing errors in the laboratory. The 331 participants with at least one analyzed stool sample will serve as denominator in the following analyses. Among those who provided one stool sample, $41 \%$ (CI 95\% 35.7-46.3) (137/331) had at least one intestinal parasite, either pathogenic or non-pathogenic, and 9\% (CI 95\% 5.9-12.0) (31/331) had more than one intestinal parasite (polyparasitism). The overall prevalence of any pathogenic parasites was $1.2 \%$ (CI 95\% 0.0-2.4) (4/331), consisting of two parasite species. As shown in Fig. 2, the prevalence of Giardia lamblia was $0.9 \%$ (3/331) and of Ascaris lumbricoides was $0.3 \%(1 / 331)$. The findings for the Entamoeba histolytica/dispar complex have to be regarded separately, as this parasite was only detected in those samples that were investigated by microscopy-based methods; hence, a differentiation between Entamoeba histolytica as a pathogenic species and Entamoeba dispar as a non-pathogenic species, which is only possible by nucleic amplification techniques, was not available. The prevalence of the complex was 1.5\% (5/331). Regarding non-pathogenic parasites, the prevalence was $25 \%$ (83/ 331) for Blastocystis hominis, 15\% (50/331) for Endolimax nana, 8\% (26/331) for Entamoeba coli, and 2\% (6/331) for Iodamoeba butschlii.

Of the 98 participants who provided a second stool sample, when both the first and second samples were analyzed together with combined microscopy techniques, the prevalence of any parasite was 52\% (51/98), with $14 \%(14 / 98)$ for more than one parasite. The only pathogenic intestinal parasite detected was Giardia lamblia in $3 \%$ of the samples (3/98). For non-pathogenic parasites, the prevalence of Blastocystis hominis was 36\% (35/98), of Endolimax nana was 22\% (22/98), of Entamoeba coli was 9\% (9/98), and of Iodamoeba butschlii was 3\% (3/98). In addition, the prevalence of Entamoeba histolytica/dispar complex was $2 \%(2 / 98)$.

As seen in Fig. 3, the second stool sample increased detection from the first to the second stool sample from $37 \%$ (33/98) to 52\% (51/98) for any parasite and from 9\% (9/ 98) to $14 \%$ (14/98) for polyparasitism, while it remained unchanged for pathogenic parasites at $2 \%(2 / 98)$.

\section{Comparison of qPCR with the combined microscopy technique}

Test results for a subset of 48 samples were compared between $\mathrm{qPCR}$ results for eight selected parasites, as outlined in the methods section, and the combined microscopy-based techniques. Two of these 50 samples could not be conclusively processed in the combined microscopy technique and therefore had to be excluded from this sub-analysis. For the eight investigated parasites, qPCR identified only two types of parasites, $B$. hominis in 54\% (26/48) and G. lamblia in 4\% (2/48). The combined microscopy technique identified $B$. hominis in 27\% (13/48) and 0\% (0/48) for G. lamblia. When comparing both techniques to identify the presence of any parasite in the samples, the prevalence estimated by qPCR was $54 \%(26 / 48)$ in contrast to $31 \%(15 / 48)$ with the combined microscopy technique $(p$ Fisher $<0.004)$. The positive and negative agreements to diagnose any parasite were $50 \%(13 / 26)$ and $91 \%(20 / 22)$, respectively, while positive and negative agreements to diagnose $B$. hominis were $48 \%(12 / 25)$ and $96 \%(22 / 23)$ respectively. With G. lamblia, there was a positive agreement of $0 \%$ and a negative agreement of $96 \%$ (Table 2).

\section{Factors associated with infection by any parasite and intestinal polyparasitism}

Associations of infection by any parasite and intestinal polyparasitism with sociodemographic characteristics (Table 3), living conditions, and hygiene behaviors (Table 4) were tested. A higher significant association was found between infection by any parasite and last deworming: less than 1 year ago with $34 \%(20 / 59)$ prevalence, more than 1 year ago with $52 \%(55 / 106)$ prevalence, and never with $36 \%$ prevalence $(48 / 135)(p=0.01)$. For infection by any parasite, a higher but non-significant association was found with civil status: being single, 34\% (34/101) prevalence; and living with a partner, $45 \%(103 / 230)$ prevalence $(p=0.06)$. There was no statistically significant difference for the variable of age between women with any parasite infection (median age 21 years (range 14-43 years)) and women without any parasite infection (median age 23 years (range $14-40$ years $))(p=0.16)$. Higher but non-significant associations with polyparasitism were found for women from 


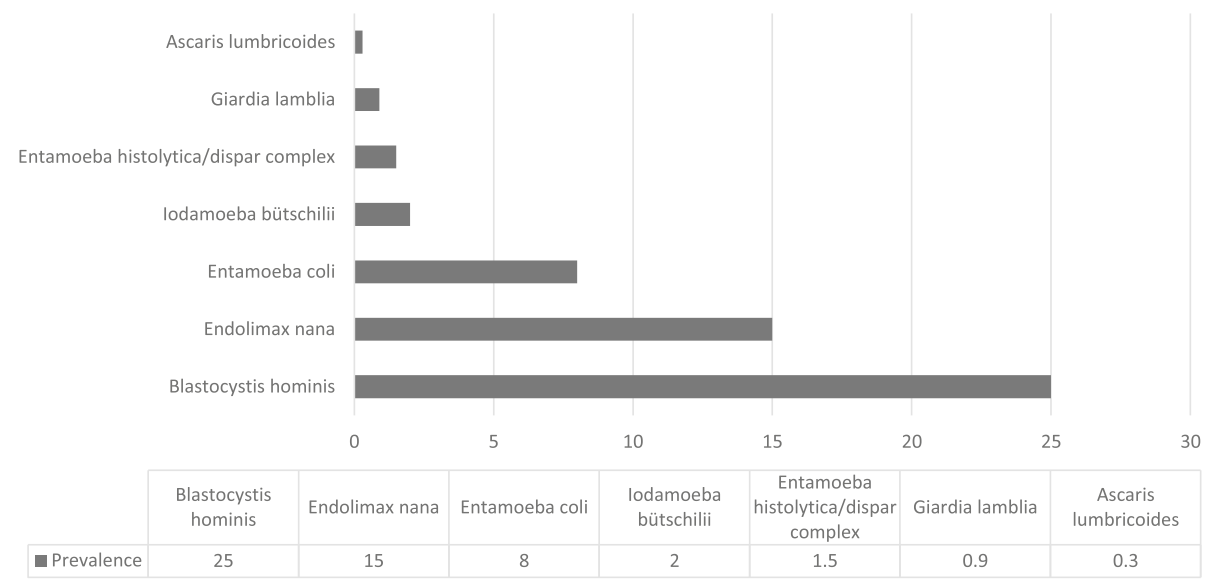

Fig. 2 Prevalence of intestinal parasitic infections in the 331 pregnant women living in poor residential areas of Bogotá. Seven intestinal parasites were found in the stool samples of participants using a combined microscopy technique

minority groups with $21 \%(5 / 24)$ prevalence compared with $9 \%(26 / 306)$ for women from majority groups $(p=$ $0.06)$, and for women without a water sink in the toilet with 14\% (14/100) prevalence compared with 7\% (17/230) for those possessing a water sink $(p=0.06)$. There was no statistically significant difference for the variable of age between women with polyparasitism (median age 22 years (range 17-37 years)) and women without polyparasitism (median age 22 years (range 14-33 years)) $(p=0.09)$. Similarly, there were no significant differences when polyparasitism was compared between parous women at $12 \%$ (18/ $149)$ and nulliparous women at $7 \%(13 / 181)(p=0.09)$. A multivariate analysis was performed including variables in which associations in bivariate analysis resulted in $p$ values lower than 0.10 . For infection by any parasite, the analyzed variables were civil status and last deworming. The only variable that remained in the equation was last deworming (more than 1 year $p=0.82$, OR 0.929, CI 0.488-1.770; never dewormed $p=0.011$, OR 1.955, CI 1.163-3.284). For polyparasitism, the analyzed variables were ethnicity, place to wash hands, age, and parity. The only variable that remained in the equation was ethnicity $(p=0.057$, OR 2.82 , CI 0.971-8.154).

\section{Discussion}

This study estimated the prevalence of intestinal parasitism and associated environmental factors in pregnant women living in poor residential areas within three districts of Bogotá, Colombia. We found a $41 \%$ prevalence of pathogenic or non-pathogenic intestinal parasites in stool samples using combined microscopy-based testing. Intestinal infections by any parasite were significantly higher in pregnant women who had never been dewormed and higher, but not significantly so, in those who were married or cohabiting. Polyparasitism in women from minority groups and those not having a water sink in the bathroom showed an important but non-significant increase in prevalence.

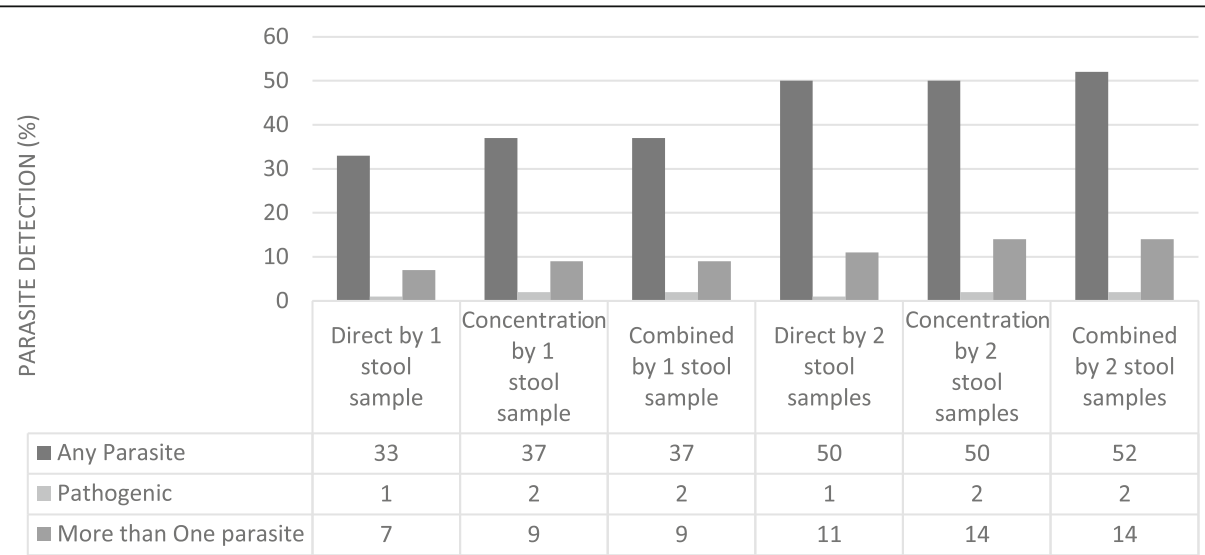

Fig. 3 Parasite detection by three methods with one and two samples $(n=98)$. Detection of any parasite and polyparasitism is increased with a combined microscopy technique and with two samples 
Table 2 Comparison between qPCR test and a combined microscopy technique in a subset of 48 participants

\begin{tabular}{lllll}
\hline & $\begin{array}{l}\text { Prevalence by combined } \\
\text { microscopy technique \% (n) }\end{array}$ & $\begin{array}{l}\text { Prevalence by qPCR } \\
\text { technique \% (n) }\end{array}$ & $\begin{array}{l}\text { Positive agreement } \\
\%^{\mathrm{b}} 95 \% \mathrm{Cl}\end{array}$ & $\begin{array}{l}\text { Negative agreement } \\
\%^{\mathrm{c}} \text { 95\%Cl }\end{array}$ \\
\hline B. hominis & $27.0(13)$ & $52.0(25)$ & 48.0 & 95.7 \\
& & & $30.0-66.5$ & $79.0-99.2$ \\
G. lamblia & $0.0(0)$ & $4.0(2)$ & 0.0 & 95.8 \\
& & & $0.0-0.0$ & $90.2-100$ \\
Any parasite & $31.0(15)$ & $54.0(26)$ & 50.0 & 90.9 \\
& & & $32.1-67.9$ & $72.2-97.5$
\end{tabular}

$n$ number of positive study participants diagnosed by each individual test

$\%=$ percentage

$\mathrm{Cl}$ confidence interval

a"Any parasite" means that, in the sample analyzed, at least one parasite has been identified, regardless of pathogenicity

${ }^{b}$ Positive agreement percentage corresponds to the number of parasites detected by combined microscopy technique and confirmed by qPCR, over the total number of parasites detected by qPCR

${ }^{c}$ Negative agreement percentage corresponds to the number of stool samples reported as negative for parasites by combined microscopy technique and confirmed by qPCR, over the total negative cases detected by qPCR

Participant selection was challenging as recruitment by phone was not allowed on account of data protection laws. Also, at UPAs, scheduled control visits for pregnant women were mixed with all other medical appointments. Given these limitations, and as UPA staff suggested that pregnant women primarily attended psychoprophylaxis courses, it was decided to focus recruitment on these activities. Once this fieldwork started, preliminary analysis revealed that attendance at these sessions mostly included nulliparous women and housewives. Based on this, and the deteriorating safety conditions in Usaquén, fieldwork in Kennedy and Usaquén districts was suspended. As Ciudad Bolívar included a majority of residents living in strata 1 and 2, and two UPAs receiving up to $80 \%$ of pregnant women in the district, systematic recruitment was concentrated at this location. As this study aimed to identify environmental factors associated with prevalence, systematic data collection was favored over representative sampling, as stated by Rothman et al. [67]. In addition to the ethical obligation to protect the safety of research assistants, community leaders supported the recruitment and data collection processes as much as possible. Thus, safety and the recruitment limitations mentioned above, as well as the unexpectedly low prevalence of pathogenic parasites in the study cohort, did not justify intensifying the recruitment activities in order to reach the calculated targeted sample size. For these reasons, data collection was stopped after the recruitment of the 550 participants in this study.

Of the 775 women who were invited to participate, $26 \%(200 / 775)$ did not accept. This value was close to the $20 \%$ estimated non-response proportion initially predicted, congruent with empirical observations in community-based studies in Latin America. In 6\% (31/ 550) of participants, house visits to observe hygiene practices and living conditions were not performed, as participants provided an incorrect address or did not attend the scheduled appointment.
Increased detection and prevalence were achieved with two stool samples, a finding congruent with Cartwright [68]. However, this was only ascertained with a subgroup of 107 participants who voluntarily provided a second stool sample. Double sampling could have been restricted by physiologic constipation inherent to pregnancy, for safety reasons, and limited geographical access. This increased detection confirmed the low prevalence of pathogenic intestinal parasites. In this study, the overall response rate for one stool sample was $60 \%(340 / 550)$, a rate considered challenging given the conditions mentioned above. Comparing pregnant women who only answered the questionnaire with those who also provided stool samples showed statistically significant differences by districts, socioeconomic strata, and health coverage. These variances related to recruitment drawbacks mainly caused by difficulties in fieldwork due to serious safety issues and the availability of pregnant women.

Although qPCR detected a higher prevalence of Blastocystis and Giardia than the combined microscopy technique, it confirmed the overall low prevalence of pathogenic parasites in this study. The low proportional positive agreement between the two techniques is expected, as qPCR is a technique with a sensitivity in stool samples close to $100 \%$ with a primer-determined specificity of $100 \%[62,63]$. In contrast, sensitivity for the combined microscopy technique with a single stool sample ranges between 86 and 95\% for nematodes [61].

In Colombia, studies have until now addressed intestinal parasitism in children and the general population with prevalence ranges reported between 11 and 50\% [2, 21]. The overall $41 \%$ prevalence of IPI in pregnant women reported here is higher than that reported in similar studies in Mexico [69], Brazil [34], northwestern and southern Ethiopia [70, 71], with prevalence figures of $38 \%, 33 \%$, $32 \%$, and $19 \%$ respectively. However, it is lower than the 
Table 3 Prevalence of any parasite infection and intestinal polyparasitism by sociodemographic characteristics of 331 participants

\begin{tabular}{|c|c|c|c|c|c|c|c|}
\hline \multirow[t]{2}{*}{ Characteristic } & \multirow[t]{2}{*}{$\mathrm{N}$} & \multicolumn{3}{|c|}{ Any parasite } & \multicolumn{3}{|c|}{ Polyparasitism } \\
\hline & & $\mathrm{n}$ & $\%$ & $p$ value & $\mathrm{N}$ & $\%$ & $p$ value \\
\hline \multicolumn{8}{|l|}{ City district of Bogotá } \\
\hline Ciudad Bolívar & 194 & 87 & 44.8 & 0.11 & 19 & 9.8 & 0.73 \\
\hline Kennedy & 115 & 45 & 39.1 & & 11 & 9.6 & \\
\hline Usaquén & 22 & 5 & 22.7 & & 1 & 4.5 & \\
\hline \multicolumn{8}{|l|}{ Stratum ${ }^{a}$} \\
\hline One & 168 & 74 & 44.0 & 0.32 & 14 & 8.6 & 0.64 \\
\hline Two & 163 & 63 & 38.7 & & 17 & 10.1 & \\
\hline \multicolumn{8}{|l|}{ Ethnicity } \\
\hline Minority group ${ }^{b}$ & 306 & 124 & 40.5 & 0.37 & 26 & 8.5 & 0.06 \\
\hline Majority group & 24 & 12 & 50.0 & & 5 & 20.8 & \\
\hline \multicolumn{8}{|l|}{ Occupation } \\
\hline Housewife & 259 & 105 & 40.5 & 0.38 & 27 & 10.4 & 0.50 \\
\hline Student & 33 & 13 & 39.4 & & 1 & 3.0 & \\
\hline Sales and services & 21 & 8 & 38.1 & & 1 & 4.8 & \\
\hline Other & 18 & 11 & 61.1 & & 2 & 11.1 & \\
\hline \multicolumn{8}{|l|}{ Level of education } \\
\hline Elementary school & 38 & 20 & 52.6 & 0.30 & 3 & 8.0 & 0.93 \\
\hline Secondary school & 234 & 92 & 39.3 & & 22 & 9.4 & \\
\hline Higher education & 59 & 25 & 42.4 & & 6 & 10.2 & \\
\hline \multicolumn{8}{|l|}{ Civil status } \\
\hline Single & 101 & 34 & 33.7 & 0.06 & 10 & 9.9 & 0.82 \\
\hline Married or cohabiting & 230 & 103 & 44.8 & & 21 & 9.1 & \\
\hline \multicolumn{8}{|c|}{ Social health security coverage } \\
\hline Yes & 291 & 120 & 41.2 & 0.88 & 25 & 8.6 & 0.19 \\
\hline No & 40 & 17 & 42.5 & & 6 & 15.0 & \\
\hline \multicolumn{8}{|c|}{ Victim of forced displacement } \\
\hline Yes & 267 & 107 & 40.1 & 0.32 & 23 & 8.6 & 0.34 \\
\hline No & 64 & 30 & 46.9 & & 8 & 12.5 & \\
\hline \multicolumn{8}{|l|}{ Monthly income $e^{c}$} \\
\hline$\leq 1$ Minimum wage & 73 & 29 & 39.8 & 0.99 & 6 & 8.2 & 0.81 \\
\hline$>1$ Minimum wage & 241 & 96 & 39.7 & & 22 & 9.1 & \\
\hline \multicolumn{8}{|l|}{ Parity } \\
\hline Nulliparous & 181 & 76 & 42.0 & 0.75 & 13 & 7.2 & 0.13 \\
\hline Parous & 149 & 60 & 40.3 & & 18 & 12.1 & \\
\hline \multicolumn{8}{|l|}{ Trimester } \\
\hline First & 61 & 21 & 34.4 & 0.46 & 7 & 11.5 & 0.50 \\
\hline Second & 149 & 64 & 43.0 & & 16 & 10.7 & \\
\hline Third & 115 & 50 & 43.5 & & 8 & 7.0 & \\
\hline
\end{tabular}

The following variables had missing data: ethnicity (1 missing), monthly income (17 missing), parity (1 missing), and trimester (6 missing)

${ }^{\text {aS }}$ ocioeconomic classification in Colombia

${ }^{\mathrm{b}}$ Afrocolombian, native ethnic people

'One minimum monthly Colombian income (for 2016 year) = USD 233
Table 4 Prevalence of intestinal parasitic infections by living conditions and hygiene habits of 331 participants

\begin{tabular}{|c|c|c|c|c|c|c|c|}
\hline \multirow[t]{2}{*}{ Characteristic } & \multirow[t]{2}{*}{ N } & \multicolumn{3}{|c|}{ Any parasite } & \multicolumn{3}{|c|}{ Polyparasitism } \\
\hline & & $n$ & $\%$ & $p$ value & $\mathrm{N}$ & $\%$ & $p$ value \\
\hline \multicolumn{8}{|l|}{ Piped water supply } \\
\hline Yes & 314 & 129 & 41.1 & 0.63 & 29 & 9.2 & 0.66 \\
\hline No & 17 & 8 & 47.1 & & 2 & 11.8 & \\
\hline \multicolumn{8}{|l|}{ Sewage } \\
\hline Yes & 315 & 129 & 41.0 & 0.47 & 29 & 9.2 & 0.65 \\
\hline No & 16 & 8 & 50.0 & & 2 & 12.5 & \\
\hline \multicolumn{8}{|l|}{ Garbage collection } \\
\hline$>2$ times per week & 277 & 112 & 40.4 & 0.44 & 26 & 9.4 & 0.96 \\
\hline$\leq 2$ times per week & 52 & 24 & 46.2 & & 5 & 9.6 & \\
\hline \multicolumn{8}{|l|}{ Presence of pets } \\
\hline No & 135 & 55 & 40.7 & 0.84 & 11 & 8.1 & 0.52 \\
\hline Yes & 196 & 82 & 41.8 & & 20 & 10.2 & \\
\hline
\end{tabular}

Last deworming of participant

$\begin{array}{llllllll}\text { Less than 1 year ago } & 59 & 20 & 33.9 & 0.01 & 5 & 8.5 & 0.32 \\ \text { More than 1 year ago } & 106 & 55 & 51.9 & & 13 & 12.3 & \\ \text { Never } & 135 & 48 & 35.6 & & 9 & 6.7 & \end{array}$

Boiling water before drinking

$\begin{array}{llllllll}\text { Yes } & 122 & 51 & 41.8 & 0.89 & 12 & 9.8 & 0.84 \\ \text { No } & 207 & 85 & 41.1 & & 19 & 9.2 & \end{array}$

Washing fruit and vegetables

$\begin{array}{llllllll}\text { Yes } & 317 & 131 & 41.3 & 0.90 & 30 & 9.5 & 1.00 \\ \text { No } & 14 & 6 & 42.9 & & 6 & 15.0 & \end{array}$

Place for washing hands at home

$\begin{array}{llllllll}\text { Sink } & 230 & 91 & 39.6 & 0.28 & 17 & 7.4 & 0.06 \\ \text { Other }^{\mathrm{a}} & 100 & 46 & 46.0 & & 14 & 14.0 & \end{array}$

Water availability for washing hands at home

$\begin{array}{llllllll}\text { From tap water } & 274 & 114 & 41.6 & 0.94 & 26 & 9.5 & 0.90 \\ \text { From water tank } & 56 & 23 & 41.1 & & 5 & 8.9 & \end{array}$

Washing hands before eating

$\begin{array}{llllllll}\text { Yes } & 211 & 92 & 43.6 & 0.27 & 21 & 10.0 & 0.63 \\ \text { No } & 120 & 45 & 37.5 & & 10 & 8.3 & \end{array}$

Washing hands after going to the toilet

$\begin{array}{llllllll}\text { Yes } & 280 & 112 & 40.0 & 0.23 & 27 & 9.6 & 0.69 \\ \text { No } & 51 & 25 & 49.0 & & 4 & 7.8 & \end{array}$

Walking barefoot at home

$$
\begin{array}{llllllll}
\text { No } & 177 & 73 & 41.2 & 0.95 & 14 & 7.9 & 0.33 \\
\text { Yes } & 154 & 64 & 41.6 & & 17 & 11.0 &
\end{array}
$$

The following variables had missing data: garbage collection (2 missing), last deworming of participants (31 missing), boiling water before drinking (2 missing), place for washing hands at home (1 missing), water availability for washing hands at home (1 missing)

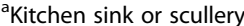


$74 \%$ and $81 \%$ prevalence found in studies in pregnant women in Venezuela [19] and New Guinea [72].

We found a low prevalence of pathogenic intestinal parasites including Giardia lamblia and Ascaris lumbricoides. These results contrasted sharply with similar studies reporting higher prevalence. For G. lamblia, the $1 \%$ prevalence reported here was lower than the reported range of $3-66 \%$ in a Brazilian cohort [34], two African studies [70, 71] and Mexico [69]. Finally, for $A$. lumbricoides, the only helminth found in this study, the prevalence of $0.3 \%$ reported here contrasted with the range of $2.9-28 \%$ from similar studies in Ethiopia [70], Mexico [69], and Ecuador [73]. For E. histolytica/dispar complex, the $1.5 \%$ prevalence reported here was lower than the $8 \%$ and $12 \%$ prevalence found in studies from Venezuela [19] and Ethiopia [70].

In this study, most positive findings were non-pathogenic intestinal parasites. Blastocystis hominis appeared in $25 \%$ of stool samples with the combined microscopy technique. This protozoon is most frequently identified in fecal samples worldwide [38, 74, 75], with reported prevalences above $50 \%$ [37] and as high as 100\% in developing countries [38]. Colombian studies in school children identified this parasite as common, with over $50 \%$ prevalence [21, 39]. Despite its debated pathogenicity, Blastocystis hominis has been reported to cause or be associated with abdominal pain and diarrhea [76], hematological abnormalities [77], pregnancy-related anemia [78], and immunosuppression [79]. Additionally, Ramirez et al. [80] reported that $72 \%$ of children positive for Blastocystis hominis were asymptomatic, with just $11 \%$ showing abdominal pain and $2 \%$ diarrhea. In contrast, a study of outpatients with digestive disorders in Spain reported a 7\% prevalence of Blastocystis hominis infestation [81]. The major routes of transmission include drinking water, food, direct human-to-human contact, and zoonotic infections [76]. Aside from Blastocystis hominis, other prevalent non-pathogenic parasites included Endolimax nana and Entamoeba coli. Regarding Endolimax nana, in this study, the prevalence of $15 \%$ in pregnant women contrasts with the 2-4\% in other South American studies [23, 34]. For Entamoeba coli, the prevalence of 5\% in this study is lower than the reported range between 6 and $19 \%$ in similar cohorts $[23,34]$ and the $9 \%$ reported in HIV-infected Tanzanian women [82].

The overall prevalence of non-pathogenic and pathogenic species can be interpreted as an important semi-quantitative indicator of the intensity of fecal-oral routes of transmission and/or contamination of food and water with feces within the study areas [21]. In this study, the dissimilar prevalence of pathogenic and non-pathogenic intestinal parasites may be explained by separately exploring the host, environment, and parasitic factors. The hosts, in this study, are pregnant women. Overall, intestinal parasites are more frequent in children and young adults than in older adults [83], facilitated, among other things, by limited hygiene habits and frequent consumption of contaminated water in these age groups [84]. The good quality of water for human consumption in Bogotá, relative to other geographical areas in Colombia, corresponds to a low risk of waterborne morbidity and mortality [85]. Open availability of broad-spectrum antiparasitic drugs [84] may occur through public health campaigns and higher access of vulnerable populations to primary care units in Bogotá. Better educational level and appropriate sanitary facilities play an important role in the prevention of parasitic infections [86], as is the case in Bogotá. Finally, the average temperature of $14{ }^{\circ} \mathrm{C}$ in Bogotá does not favor most helminthic life cycles. However, commensal non-pathogenic protozoal species are less demanding in terms of environmental conditions [21]. It is possible that these commensal parasites have more permissive growth requirements in pregnant women compared with pathogenic parasites.

In this study, any intestinal parasite could be detected in $41 \%$ of pregnant women. This is comparable to similar studies in Ethiopia and Brazil [16, 34, 70], reporting prevalence between 32 and $57 \%$. Given that many of the IPI share common routes of transmission, polyparasitism is a common occurrence in exposed populations. In this research, the prevalence of polyparasitism was 9\%, within the range found in similar studies which reported prevalence as low as $6.6 \%$ in Ethiopian pregnant women [16] and up to $33 \%$ in a Brazilian cohort [34]. This variability may be explained by geographic differences, age variations, diversity of health conditions and cultural practices in different study areas [70].

For pregnant women infected with any intestinal parasite, two risk factors appeared to be important, namely the time since the last deworming procedure and civil status. Pregnant women who had never been dewormed showed a statistically significant higher prevalence of infection by any intestinal parasite. However, although prophylactic deworming programs in children and women of reproductive age have been recommended $[87,88]$, their effectiveness in health outcomes is unclear $[89,90]$. Our finding may support the effectiveness of deworming programs as we could show a decreasing prevalence of intestinal parasites. Women who were married or living with a partner showed a non-significant trend toward a higher prevalence of intestinal parasitism. Derso et al. [70] did not find a difference in IPI in pregnant women when considering marital status. In contrast, van Eijk et al. [13] found that married women had a lower prevalence of hookworm infections.

The prevalence of polyparasitism was higher in women from minority groups. These groups, which include indigenous people, African Colombians, and Raizals (from the Caribbean island), likely immigrated into Bogotá from 
other regions with a high risk of polyparasitism [21] and may have arrived with undiagnosed infestations. Prevalence of polyparasitism was also higher in pregnant women living without a water sink. Having a water sink facilitates the hygienic habit of washing hands before and after going to the bathroom and after changing diapers. Although this variable was assessed recently in Kenyan children living in urban slums [91], it has not been specifically assessed in studies with pregnant women.

\section{Conclusions}

This study has been the first conducted with pregnant women in Colombia that estimates the prevalence of and factors associated with intestinal parasitism, evaluating vulnerable populations living in conditions of poverty and social inequality in the largest city in the country. A low prevalence of pathogenic parasites was found in pregnant women. At the same time, a high prevalence of parasites was identified with disputed pathogenicity indicating fecal-oral contamination. A significant association was identified between time since last deworming and infection by any parasite. Higher but non-significant prevalence of intestinal parasites was found in pregnant women living with a partner (by any parasite infection) and in pregnant women belonging to minority ethnic groups and those without handwashing facilities (by polyparasitism).

This study provides guidance to health authorities regarding some risk factors to prevent intestinal parasitism in pregnant women. The high prevalence of parasites with debated pathogenicity points to maintaining and strengthening educational interventions to eliminate fecal-oral transmission routes, including handwashing during daily activities, particularly after using washrooms and, in child caring settings, after diaper changes and cleaning. Owing to their harmful potential, it is important to continue research that identifies causes for the high prevalence of commensal intestinal parasites.

\footnotetext{
Abbreviations

CDC: Center for Disease Control and Prevention; Cl: Confidence interval; Ct: Cycle threshold value; DHS: Demographic and Health Survey; DNA: Deoxyribonucleic acid; HIV: Human immunodeficiency virus; IPI: Intestinal parasitic infections; OR: Odds ratio; PCR: Polymerase chain reaction; GPCR: Quantitative polymerase chain reaction; STH: Soil-transmitted helminthiasis; UPA : Unidad Primaria de Atención; Primary Attention Unit; USD: United States dollar; WB: WB kit (sodium iodide method); WHO: World Health Organization
}

\section{Acknowledgements}

Special thank you to Maria Antonia Gaona de Hernández who performed quality control analysis of the samples using the combined microscopy technique; to Doctor Juan David Ramirez Gonzalez and Angie Johanna Sanchez Castro, who both analyzed the samples using the qPCR technique; to Audrey Holmes, MA, from Edanz Group (www.edanzediting.com/ac) for editing a draft of the manuscript; and to Doctor Otto Sanchez Contreras, University of Ontario Institute of Technology, Canada, for his support to the Principal Investigator in writing the final version of the manuscript.

\section{Funding}

This research was funded by Fondo de Investigaciones de la Universidad del Rosario (FIUR). This agency did not have a role in the study design, collection, analysis and interpretation of data. It made available an external editor for an early draft of the manuscript.

\section{Availability of data and materials}

The datasets used and/or analyzed during the current study are not publicly available due to Colombian data protection laws, but are available from the corresponding author on reasonable request.

\section{Authors' contributions}

All authors of this manuscript, KR, MD, GF, AP and AE, met with the four ICMJE criteria for authorship, as follows: "1. Made substantial contributions to conception and design, or acquisition of data, or analysis and interpretation of data; 2 . Been involved in drafting the manuscript or revising it critically for important intellectual content; 3. Given final approval of the version to be published. Each author should have participated sufficiently in the work to take public responsibility for appropriate portions of the content; and 4. Agreed to be accountable for all aspects of the work in ensuring that questions related to the accuracy or integrity of any part of the work are appropriately investigated and resolved." All authors have read and approved this manuscript.

\section{Ethics approval and consent to participate}

The study was approved by the Ethics Committees of Universidad del Rosario, Bogotá, Colombia (CEI-ABN026-000343) and Ludwig-MaximiliansUniversität, Munich, Germany (231-15). Written informed consent was obtained from each participant. According to Colombian legislation, when research participants are under 18 years of age, written informed consent is required from parents or guardians and written assent from the under-aged participant. When she only has one parent, the single parent must certify and sign the informed consent form of the custodian. This study fulfilled these requirements. After signing the informed consent form, a unique identification code was assigned to every woman and her questionnaire was labeled with this code. The study was carried out pseudonymously to notify participants who were diagnosed with IPI.

\section{Consent for publication}

Not applicable.

\section{Competing interests}

The authors declare that they have no competing interests.

\section{Publisher's Note}

Springer Nature remains neutral with regard to jurisdictional claims in published maps and institutional affiliations.

\section{Author details}

${ }^{1}$ Escuela de Medicina y Ciencias de la Salud, Universidad del Rosario, Bogotá, Colombia. ${ }^{2}$ Center for International Health, Medical Center of the University of Munich (LMU), Munich, Germany. ${ }^{3}$ Institute and Outpatient Clinic for Occupational, Social and Environmental Medicine, University Hospital of Munich (LMU), Munich, Germany. ${ }^{4}$ Division of Infectious Diseases and Tropical Medicine, Medical Center of the University of Munich (LMU), Munich, Germany. ${ }^{5}$ Department of Obstetrics and Gynecology, University Hospital, LMU Munich, Munich, Germany.

Received: 15 January 2018 Accepted: 17 August 2018 Published online: 29 August 2018

\section{References}

1. World Health Organization: Soil-transmitted helminth infections. http:// www.who.int/news-room/fact-sheets/detail/soil-transmitted-helminthinfections. Accessed 28 Apr 2018.

2. Pan American Health Organization. Epidemiological profiles of neglected diseases and other infections related to poverty in Latin America and the Caribbean. https://www.paho.org/hq/dmdocuments/2009/nds-epi-profilesfinal-sst-24-set.pdf. Accessed 28 Apr 2018.

3. Ehrenberg JP, Ault SK. Neglected diseases of neglected populations: thinking to reshape the determinants of health in Latin America and the 
Caribbean. BMC Public Health. 2005;5:119. https://doi.org/10.1186/14712458-5-119.

4. Mahande AM, Mahande MJ. Prevalence of parasitic infections and associations with pregnancy complications and outcomes in northern Tanzania: a registry-based cross-sectional study. BMC Infect Dis. 2016;16:78. https://doi.org/10.1186/s12879-016-1413-6.

5. Saboyá MI, Catalá L, Ault SK, Nicholls RS. Prevalence and intensity of infection of soil-transmitted helminths in Latin America and the Caribbean countries: mapping at second administrative level 2000-2010. Pan American Health Organization 2011. https://www.paho.org/hq/dmdocuments/2011/ STH-segundo-nivel-prevalence-LAC-MARCH-2011.pdf. Accessed 28 Apr 2018.

6. Lozano R, Naghavi M, Foreman K, Lim S, Shibuya K, Aboyans V, et al. Global and regional mortality from 235 causes of death for 20 age groups in 1990 and 2010: a systematic analysis for the global burden of disease study 2010. Lancet. 2012;380(9859):2095-128.

7. Cabrera-Licona A, Solano-González E, Fonseca-Liñán R, Bazán-Tejeda ML, Argüello-García R, Bermúdez-Cruz RM, et al. Expression and secretion of the Giardia duodenalis variant surface protein 9B10A by transfected trophozoites causes damage to epithelial cell monolayers mediated by protease activity. Exp Parasitol. 2017;179:49-64.

8. Yoder JS, Gargano JW, Wallace RM, Beach MJ. Giardiasis surveillance-United States, 2009-2010. MMWR Surveill Summ. 2012;61(5): 13-23.

9. Halliez MCM, Buret AG. Extra-intestinal and long term consequences of Giardia duodenalis infections. World I Gastroenterol. 2013:19(47):8974-85.

10. King JD, Endeshaw T, Escher E, Alemtaye G, Melaku S, Gelaye W, et al. Intestinal parasite prevalence in an area of Ethiopia after implementing the SAFE strategy, enhanced outreach services, and health extension program. PLoS Negl Trop Dis. 2013;7(6):e2223. https://doi.org/10.1371/journal.pntd. 0002223.

11. Elyana FN, Al-Mekhlafi HM, Ithoi I, Abdulsalam AM, Dawaki S, Nasr NA, et al. A tale of two communities: intestinal polyparasitism among orang Asli and Malay communities in rural Terengganu, Malaysia. Parasit Vectors. 2016;9: 398. https://doi.org/10.1186/s13071-016-1678-z.

12. Speich B, Marti H, Ame SM, Ali SM, Bogoch II, Utzinger J, et al. Prevalence of intestinal protozoa infection among school-aged children on Pemba Island, Tanzania, and effect of single-dose albendazole, nitazoxanide and albendazole-nitazoxanide. Parasit Vectors. 2013;6:3. https://doi.org/10.1186/ 1756-3305-6-3.

13. van Eijk A, Lindblade KA, Odhiambo F, Peterson E, Rosen DH, Karanja D, et al. Geohelminth infections among pregnant women in rural western Kenya; a cross-sectional study. PLoS Negl Trop Dis. 2009;3(1):e370. https://doi.org/ 10.1371/journal.pntd.0000370.

14. Tefera T, Mebrie G. Prevalence and predictors of intestinal parasites among food handlers in Yebu town, Southwest Ethiopia. PLoS One. 2014;9(10): e1 10621. https://doi.org/10.1371/journal.pone.0110621.

15. Hotez PJ, Fenwick A, Savioli L, Molyneux DH. Rescuing the bottom billion through control of neglected tropical diseases. Lancet. 2009;373(9674):1570-5.

16. Belyhun Y, Medhin G, Amberbir A, Erko B, Hanlon C, Alem A, et al. Prevalence and risk factors for soil-transmitted helminth infection in mothers and their infants in Butajira, Ethiopia: a population based study. BMC Public Health. 2010;10:21. https://doi.org/10.1186/1471-2458-10-21.

17. Tay SC, Nani EA, Walana W. Parasitic infections and maternal anaemia among expectant mothers in the Dangme East District of Ghana. BMC Res Notes. 2017;10:3. https://doi.org/10.1186/s13104-016-2327-5.

18. Getachew M, Yewhalaw D, Tafess K, Getachew Y, Zeynudin A. Anaemia and associated risk factors among pregnant women in Gilgel gibe dam area, Southwest Ethiopia. Parasit Vectors. 2012;5:296. https://doi.org/10.1186/17563305-5-296.

19. Rodríguez-Morales AJ, Barbella RA, Case C, Arria M, Ravelo M, Perez H, et al. Intestinal parasitic infections among pregnant women in Venezuela. Infect Dis Obstet Gynecol. 2006;2006:23125. https://doi.org/10.1155/IDOG/2006/ 23125.

20. Gyorkos TW, Larocque R, Casapia M, Gotuzzo E. Lack of risk of adverse birth outcomes after deworming in pregnant women. Pediatr Infect Dis J. 2006; 25(9):791-4.

21. Encuesta nacional de parasitismo intestinal en población escolar, Colombia, 2012-2014. Ministerio de Salud y Proteccion Social, Universidad de Antioquia. 2015. https://www.minsalud.gov.co/sites/rid/Lists/ BibliotecaDigital/RIDE/NS/PP/ET/encuesta-nacional-de-parasitismo-20122014.pdf. Accessed 29 Apr 2018.
22. Valderrama J, Arias V, Parra E. Cuál es su diagnóstico? Ascaridiosis. Biomedica. 2005;25(1):9-10. 148-151

23. Acurero E, Díaz I, Díaz N, Bracho A, Ferrer M, Matheus A. Prevalencia de enteroparásitos en embarazadas de la maternidad "Dr. Armando Castillo Plaza" en Maracaibo, Venezuela. Kasmera. 2008;36(2):148-58.

24. Solano L, Acuña I, Barón M, Morón de Salim A, Sánchez A. Asociación entre pobreza e infestación parasitaria intestinal en preescolares, escolares y adolescentes del sur de Valencia estado Carabobo-Venezuela. Kasmera. 2008;36(2):137-47.

25. Jerlström-Hultqvist J, Ankarklev J, Svärd SG. Is human giardiasis caused by two different Giardia species? Gut Microbes. 2010;1(6):379-82.

26. Escobedo AA, Cimerman S. Giardiasis: a pharmacotherapy review. Expert Opin Pharmacother. 2007;8(12):1885-902.

27. Batista-Rojas O, Martínez-Sánchez R. Intervención comunitaria en las parasitosis intestinales parroquia Santa Bárbara, estado Anzoátegui, 2010. Rev Haban Cienc Med. 2011;10(2):233-45.

28. Pezzani BC, Minvielle MC, Ciarmela ML, Apezteguía MC, Basualdo JA. Participación comunitaria en el control de las parasitosis intestinales en una localidad rural de Argentina. Rev Panam Salud Publica. 2009;26(6):471-7.

29. Agudelo-Lopez S, Gómez-Rodríguez L, Coronado X, Orozco A, ValenciaGutiérrez C, Restrepo-Betancur L, et al. Prevalencia de parasitosis intestinales y factores asociados en un corregimiento de la Costa Atlántica Colombiana. Rev Salud Pública. 2008;10(4):633-42.

30. Arias I, González M. Determinación de la coinfección entre enterobacterias, parásitos y noravirus en niños de edades entre tres meses y cinco años con enfermedad diarreica aguda en los barrios Arabia y Jerusalén de la Localidad de Ciudad Bolívar, Bogotá-Colombia. Pontificia Universidad Javeriana. 2009. https://repository.javeriana.edu.co/handle/10554/8408. Accessed 30 Apr 2018.

31. Rodriguez V, Espinosa O, Carranza JC, Duque S, Arevalo A, Clavijo JA, et al. Giardia duodenalis genotypes found in the Instituto Colombiano de Bienestar familiar day care centers and dogs in Ibague. Colombia Biomédica. 2014;34(2):271-81.

32. González-Vázquez MC, Carabin-Lima A, Baylon-Pacheco L, Rosales-Encina JL. De amibas y amebiasis: Entamoeba histolytica. Elementos: Ciencia y Cultura. 2012;87(19):13-8.

33. Rojas CL, Núñez CF, Aguiar PH, Silva-Ayçaguer LC, Álvarez D, Martínez R, et al. Segunda encuesta nacional de infecciones parasitarias intestinales en Cuba, 2009. Rev Cubana Med Trop. 2012;64(1):15-21.

34. dos Santos MC, Costa-Cruz JM, Carvalho-Neto C, Lima MMR, Cristina M. Enteric parasites and commensals in pregnant women seen at the university hospital, Federal University of Uberlândia, state of Minas Gerais, Brazil. Rev Inst Med Trop Sao Paulo. 1998;40(3):193-5.

35. Guzmán CE, López MC, Reyes P, Gómez JE, Corredor A, Agudelo C. Diferenciación de Entamoeba histolytica y Entamoeba dispar en muestras de materia fecal por detección de adhesina de E. histolytica mediante ELISA. Biomedica. 2001;21(2):167-71.

36. Gallego ML, Gómez-Marín JE, Torres E, Lora F. Prevalencia de Entamoeba histolytica en asentamientos temporales post-terremoto de la ciudad de Armenia. Infection. 2003;7(4):190-4.

37. Ramirez JD, Sanchez LV, Bautista DC, Corredor AF, Florez AC, Stensvold CR. Blastocystis subtypes detected in humans and animals from Colombia. Infect Genet Evol. 2014;22:223-8.

38. El Safadi D, Gaayeb L, Meloni D, Cian A, Poirier P, Wawrzyniak I, et al. Children of Senegal River basin show the highest prevalence of Blastocystis sp. ever observed worldwide. BMC Infect Dis. 2014;14:164. https://doi.org/10. 1186/1471-2334-14-164.

39. Londoño-Franco ÁL, Loaiza-Herrera J, Lora-Suárez FM, Gómez-Marín JE. Frecuencia y fuentes de Blastocystis sp. en niños de 0 a 5 años de edad atendidos en hogares infantiles públicos de la zona urbana de Calarcá, Colombia. Biomedica. 2014;34(2):218-27.

40. Alcaldía Mayor de Bogotá, Secretaría General. El clima de Bogotá. http:// www.bogota.gov.co/ciudad/clima. Accessed 01 May 2018.

41. Departamento Administrativo Nacional de Estadística (DANE). Boletín Técnico por Departamento 2016. Pobreza Monetaria y Multidimensional en Colombia 2016. https://www.dane.gov.co/files/investigaciones/condiciones_ vida/pobreza/bol_pobreza_16.pdf. Accessed 01 May 2018.

42. Alcaldía Mayor de Bogotá. Secretaría Distrital de Planeación. Información, Cartografía y Estadística. Repositorio de documentos estadísticos. Serie Poblacional 1995-2020 Bogotá y sus localidades. http://www.sdp.gov.co/ gestion-estudios-estrategicos/informacion-cartografia-y-estadistica/ 
consulta?combine=localidades\&field_dice_componentes_tid=All\&field_ dice_tema_social_tid=All\&field_dice_tema_territorial_tid=All\&field_dice_ tema_economico_tid=All. Accessed 21 Aug 2018.

43. Departamento Administrativo Nacional de Estadística (DANE). Necesidades Básicas Insatisfechas-NBI. Informes especiales.Necesidades Básicas insatisfechas-desagregadas. http://www.dane.gov.co/index.php/estadisticaspor-tema/pobreza-y-condiciones-de-vida/necesidades-basicas-insatisfechasnbi. Accessed 02 May 2018.

44. Unidad para la Atención y Reparación Integral a las Víctimas en Colombia. Registro Unico de Victimas (RUV). Reporte de victimas de desplazamiento forzado recibidas cada año en Bogotá D.C. 2017. https://www. unidadvictimas.gov.co/es/registro-unico-de-victimas-ruv/37394. Accessed 02 May 2018.

45. Ibáñez AM, Moya A. La población desplazada en Colombia: Examen de sus condiciones socioeconómicas y análisis de las políticas actuales. B. Condiciones de vida en los municipios receptores, p.50-60. http://www. acnur.org/fileadmin/Documentos/Publicaciones/2008/6682.pdf. Accessed 02 May 2018.

46. Alcaldía Mayor de Bogotá, Secretaría Distrital de Planeación. Bogotá Ciudad de Estadísticas. Boletín Número 22. Densidades urbanas: el caso de Bogotá. Hacinamiento en Bogotá. http://www.sdp.gov.co/sites/default/files/dice105cartilladensidadurbana-2010.pdf. Accessed 03 May 2018.

47. Departamento Administrativo Nacional de Estadística (DANE). Estratificación socioeconómica para servicios públicos domiciliarios Bogotá: Preguntas Frecuentes. https://www.dane.gov.co/index.php/servicios-al-ciudadano/ servicios-de-informacion/estratificacion-socioeconomica\#preguntasfrecuentes. Accessed 03 May 2018.

48. Departamento Administrativo Nacional de Estadística (DANE). Metodología de estratificación socioeconómoca urbana para servicios públicos domiciliarios. Enfoque conceptual. Grupo de Estratificación. Dirección de Geoestadística. Versión diciembre 2015. p. 35. https://www. dane.gov.co/files/geoestadistica/estratificacion/EnfoqueConceptual.pdf. Accessed 21 Aug 2018

49. Ministerio de Salud y Protección Social. Lineamiento de desparasitación antihelmíntica masiva, en el marco de la estrategia "Quimioterapia Preventiva antihelmíntica de OMS". https://www.minsalud.gov.co/sites/rid/ Lists/BibliotecaDigital/RIDE/NS/PP/ET/ LINEAMIENTO\%20DESPARASIT\%20ANTIHELM\%C3\%8DNTICA\%20080122014. pdf. Accessed 15 July 2018.

50. Alcaldía Mayor de Bogotá, Alta Consejera para los Derechos de las Víctimas, la Paz y la Reconciliación. Sistema Distrital de Atención y Reparación a las víctimas. Plan de Acción Distrital 2016-2020. Lineamientos para la implementación de la Política Pública de Prevención y Protección, Asistencia, Atención y Contribución a la Reparación Integral a las Víctimas. http://www.victimasbogota.gov.co/ sites/default/files/marco-legal/Documento\%20PAD\%202018.pdf. Accessed 03 May 2018.

51. Alcaldía Mayor de Bogotá. Secretaría General. Mapa de Localidades Bogotá. http://www.bogota.gov.co/localidades/mapa. Accessed 21 Aug 2018.

52. Alcaldía Mayor de Bogotá, Secretaría Distrital de Planeación. Conociendo la localidad de Ciudad Bolívar: Diagnóstico de los aspectos físicos, demográficos y socioeconómicos. 2009. http://oab2.ambientebogota.gov. co/es/documentacion-e-investigaciones/resultado-busqueda/conociendo-lalocalidad-de-ciudad-bolivar. Accessed 04 May 2018.

53. ICF International. 2011. Demographic and Health Surveys Methodology Questionnaires: Household, Woman's, and Man's. MEASURE DHS Phase III: Calverton, Maryland, USA. https://dhsprogram.com/pubs/pdf/DHSQ6/DHS6_ Questionnaires_5Nov2012_DHSQ6.pdf. Accessed 04 May 2018.

54. Fescina RH, De Murcio B, Diaz-Rosello JL, Martinez G, Serruya S, Duran P. Salud y Sexual y Reproductiva: Guías para el continuo de atención de la mujer y el recién nacido focalizada en APS. Centro Latinoamericano de Perinatologia/Saludo de la Mujer y Reproductiva (CLAP/SMR). Organización Panamericana de la Salud. 2011. https://www.paho.org/clap/index. php?option=com_docman\&view=download\&category_slug=salud-de-mujerreproductiva-materna-y-perinatal\&alias=416-salud-sexual-y-reproductiva-guiaspara-el-continuo-de-atencion-de-la-mujer-y-el-recien-nacido-focalizadas-enaps-3-ed-6\&ltemid=219\&lang=es. Accessed 04 May 2018

55. Ministerio de Salud y Protección Social de Colombia. Diagnóstico de las condiciones sanitarias de la vivienda a nivel familiar. 2006. https://www. minsalud.gov.co/sites/rid/Lists/BibliotecaDigital/RIDE/NS/PP/SA/ficha-decaracterizacion-a-nivel-familiar.pdf. Accessed 04 May 2018.
56. Guidance on regulations for the transport of infectious substances 20172018. World Health Organization (WHO). 2017; p.9-10. http://apps.who.int/ iris/bitstream/handle/10665/254788/WHO-WHE-CPI-2017.8-eng. pdf?sequence=1. Accessed 04 May 2018.

57. Oguoma $V$, Ekwunife $C$. The need for a better method: comparison of direct smear and formol-ether concentration techniques in diagnosing intestinal parasites. Internet J Trop Med. 2006;3(2).

58. Flórez-Sánchez AC. Lineamiento para la realización de coproanálisis o coprológico y modelo de reporte de resultados como examen de diagnóstico en el laboratorio clínico. Instituto Nacional de Salud (INS); Laboratorio Nacional de Referencia de Parasitologia. https://www.academia. edu/34523158/LINEAMIENTO_PARA_LA_REALIZACI\%C3\%93N_DE_ COPROAN\%C3\%81LISIS_O_COPROL\%C3\%93GICO_Y_MODELO_DE_ REPORTE_DE_RESULTAD. Accessed 05 May 2018.

59. Mendoza D, Núñez-Fernández FÁ, ÁArturo E-C, Pelayo L, et al. Utilidad de 2 métodos coproparasitológicos y su empleo en un ensayo terapéutico antigiardiásico. Rev Cubana Med Trop. 2003;55(3):174-8.

60. López MC, Moncada LI, Ariza-Araújo Y, Fernández-Niño JA, Reyes P, Nicholls RS. Evaluación de tres pruebas para el diagnóstico de geohelmintos en Colombia. Biomedica. 2013;33(1):128-36.

61. Restrepo-Von Schiller IC, Mazo-Berrío LP, Salazar-Giraldo ML, MontoyaPalacio MN, Botero-Garcés JH. Evaluación de tres técnicas coproparasitoscópicas para el diagnóstico de geohelmintos intestinales. latreia. 2013;26(1):15-24.

62. Schuurman T, Lankamp P, van Belkum A, Kooistra-Smid M, van Zwet A. Comparison of microscopy, real-time PCR and a rapid immunoassay for the detection of Giardia lamblia in human stool specimens. Clin Microbiol Infect. 2007;13(12):1186-91.

63. Elsafi SH, Al-Maqati TN, Hussein MI, Adam AA, Hassan MM, Al Zahrani EM. Comparison of microscopy, rapid immunoassay, and molecular techniques for the detection of Giardia lamblia and Cryptosporidium parvum. Parasitol Res. 2013;112(4):1641-6.

64. Mejia R, Vicuña Y, Broncano N, Sandoval C, Vaca M, Chico M, et al. A novel, multi-parallel, real-time polymerase chain reaction approach for eight gastrointestinal parasites provides improved diagnostic capabilities to resource-limited at-risk populations. Am J Trop Med Hyg. 2013;88(6):1041-7.

65. Stensvold CR, Ahmed UN, O'Brien Andersen L, Nielsen HV. Development and evaluation of a genus-specific, probe-based, internal-process-controlled real-time PCR. assay for sensitive and specific detection of Blastocystis spp. J Clin Microbiol. 2012;50(6):1847-51.

66. U.S. Department of Health and Human Services. Statistical Guidance on Reporting Results from Studies Evaluating Diagnostic Tests-Guidance for Industry and FDA Staff. https://www.fda.gov/downloads/MedicalDevices/ DeviceRegulationandGuidance/GuidanceDocuments/ucm071287.pdf. Accessed 15 July 2018.

67. Rothman KJ, Gallacher JE, Hatch EE. Why representativeness should be avoided. Int J Epidemiol. 2013;42(4):1012-4.

68. Cartwright C. Utility of multiple-stool-specimen ova and parasite examinations in a high-prevalence setting. J Clin Microbiol. 1999;37(8):2408-11.

69. Rodríguez-Garcia R, Rodriguez-Guzmán LM, Sánchez-Maldonado MI, GómezDelgado A, Rivera-Cedillo R. Prevalence and risk factors associated with intestinal parasites in pregnant women and their relation to the infant's birth weight. Ginecol Obstet Mex. 2002;70:338-43.

70. Derso A, Nibret E, Munshea A. Prevalence of intestinal parasitic infections and associated risk factors among pregnant women attending antenatal care center at Felege Hiwot referral hospital, northwest Ethiopia. BMC Infect Dis. 2016;16(1):530. https://doi.org/10.1186/s12879-016-1859-6.

71. Gedefaw L, Ayele A, Asres Y, Mossie A. Anemia and associated factors among pregnant women attending antenatal care clinic in Wolayita Sodo town, Southern Ethiopia. Ethiop J Health Sci. 2015;25(2):155-62.

72. Phuanukoonnon S, Michael A, Kirarock WS, Pomat WS, van den Biggelaar AH. Intestinal parasitic infections and anaemia among pregnant women in the highlands of Papua New Guinea. P N G Med J. 2013;56(3-4):119-25.

73. Cooper PJ, Chico ME, Platts-Mills TA, Rodrigues LC, Strachan DP, Barreto ML. Cohort profile: the Ecuador life (ECUAVIDA) study in Esmeraldas Province, Ecuador. Int J Epidemiol. 2015;44(5):1517-27.

74. Velarde L, Mendoza M. Prevalencia de Blastocystis hominis en menores de 12 años de una población mexicana urbana. Rev Cubana Pediatr [Internet]. 2006;78(4). Available in: http://scielo.sld.cu/scielo.php?script=sci_arttext\&pid= S0034-75312006000400006\&lng=es. Access 21 Ago 2018. 
75. Tan KSW. New insights on classification, identification, and clinical relevance of Blastocystis spp. Clin Microbiol Rev. 2008;21(4):639-65.

76. Fletcher SM, Stark D, Harkness J, Ellis J. Enteric protozoa in the developed world: a public health perspective. Clin Microbiol Rev. 2012;25(3):420-49.

77. Javaherizadeh H, Khademvatan S, Soltani S, Torabizadeh M, Yousefi E. Distribution of haematological indices among subjects with Blastocystis hominis infection compared to controls. Prz Gastroenterol. 2014;9(1):38-42.

78. El Deeb HK, Salah-Eldin H, Khodeer S. Blastocystis hominis as a contributing risk factor for development of iron deficiency anemia in pregnant women. Parasitol Res. 2012;110(6):2167-74.

79. Tan KS, Mirza H, Teo JD, Wu B, Macary PA. Current views on the clinical relevance of Blastocystis spp. Curr Infect Dis Rep. 2010;12(1):28-35.

80. Ramirez JD, Florez C, Olivera M, Bernal MC, Giraldo JC. Blastocystis subtyping and its association with intestinal parasites in children from different geographical regions of Colombia. PLoS One. 2017;12(2):e0172586. https:// doi.org/10.1371/journal.pone.0172586.

81. González-Moreno O, Domingo L, Teixidor J, Gracenea M. Prevalence and associated factors of intestinal parasitisation: a cross-sectional study among outpatients with gastrointestinal symptoms in Catalonia, Spain. Parasitol Res. 2011;108(1):87-93.

82. Zack RM, Golan J, Aboud S, Msamanga G, Spiegelman D, Fawzi W. Risk factors for preterm birth among HIV-infected Tanzanian women: a prospective study. Obstet Gynecol Int. 2014;2014:261689. https://doi.org/10. $1155 / 2014 / 261689$

83. Visser S, Giatti LL, Chaves de Carvalho RA, Guerreiro JC. Estudo da associação entre fatores socioambientais e prevalência de parasitose intestinal em área periférica da cidade de Manaus (AM, Brasil). Ciênc Saúde Coletiva. 2011;16(8):3481-92.

84. Casavechia MT, Lonardoni MV, Venazzi EA, Campanerut-Sa PA, da Costa Benalia HR, Mattiello MF, et al. Prevalence and predictors associated with intestinal infections by protozoa and helminths in southern Brazil. Parasitol Res. 2016;115(6):2321-9.

85. Guzman BL, Nava G, Díaz- Bevilacqua P. La calidad del agua para consumo humano y su asociación con la morbimortalidad en Colombia, 2008-2012. Biomedica. 2015;35(Supl.2):177-90.

86. Wekesa AW, Mulambalah CS, Muleke Cl, Odhiambo R. Intestinal helminth infections in pregnant women attending antenatal clinic at Kitale District hospital, Kenya. J Parasitol Res. 2014;2014:823923. https://doi.org/10.1155/ 2014/823923.

87. Uniting to Combat Neglected Tropical Diseases. London Declaration on Neglected Tropical Diseases 2018. https:/unitingtocombatntds.org/londondeclaration-neglected-tropical-diseases/. Accessed 15 July 2018.

88. Mofid LS, Gyorkos TW. The case for maternal postpartum deworming. In: Clements ACA, editor. PLoS Negl Trop Dis 11. San Francisco, CA USA2017. e0005203. https://doi.org/10.1371/journal.pntd.0005203.

89. Thayer WM, Clermont A, Walker N. Effects of deworming on child and maternal health: a literature review and meta-analysis. BMC Public Health. 2017:17(Suppl 4):830. https://doi.org/10.1186/s12889-017-4747-0.

90. Taylor-Robinson DC, Maayan N, Soares-Weiser K, Donegan S, Garner P. Deworming drugs for soil-transmitted intestinal worms in children: effects on nutritional indicators, haemoglobin, and school performance. Cochrane Database Syst Rev 2015, Issue 7. Art. No.: cd000371. https://doi.org/10.1002/ 14651858.cd000371.pub6.

91. Worrell CM, Wiegand RE, Davis SM, Odero KO, Blackstock A, Cuellar VM, et al. A cross-sectional study of water, sanitation, and hygiene-related risk factors for soil-transmitted helminth infection in urban school- and preschool-aged children in Kibera, Nairobi. PLoS One. 2016;11(3):e0150744. https://doi.org/10.1371/journal.pone.0150744.

92. Wolff L, cartographer. Own work, Public Domain. Mapa Administrativo. Bogotá 2006. https://commons.wikimedia.org/wiki/File:Mapa_administrativa_ Bogota.png. Accessed 5 May 2018.

\section{Ready to submit your research? Choose BMC and benefit from:}

- fast, convenient online submission

- thorough peer review by experienced researchers in your field

- rapid publication on acceptance

- support for research data, including large and complex data types

- gold Open Access which fosters wider collaboration and increased citations

- maximum visibility for your research: over $100 \mathrm{M}$ website views per year

At BMC, research is always in progress.

Learn more biomedcentral.com/submissions 